\title{
Od zarządzania zasobami ludzkimi do gospodarowania kapitałem ludzkim
}

https://doi.org/10.33141/po.2005.04.05

\section{Anna Lipka}

Przegląd Organizacji, Nr 4 (783), 2005, ss. 22-25

www.przegladorganizacji.pl Towarzystwo Naukowe Organizacji i Kierownictwa (TNOiK)
Podstawowe pytanie niniejszych rozważań brzmi: Czy tradycyjny, nawet ten wzbogacony o wymiar taktyczny i strategiczny (por. tabela) podział funkcji personalnych już się przeżył i nie odpowiada wymogom czasu? Jeśli tak, to jak wygląda nowa architektura (sposób skonfigurowania działań personalnych umożliwiających organizacji uzyskanie i utrzymanie zakładanej przez nią pozycji konkurencyjnej, tj. ich treść i zakres) zarządzania zasobami ludzkimi (dalej - zzl) i czy w ogóle jeszcze powinno mówić się o zzl czy też raczej o gospodarowaniu kapitałem ludzkim (dalej gkl)?

Za tą drugą opcją przemawiają konkretne względy. Po pierwsze, pracownicy utożsamiani są obecnie nie tyle z zasobem przedsiębiorstwa - pracą (wyróżnianym obok kapitału, czyli majątku mającego postać fizyczną), lecz określani są kapitałem.

Po drugie, ściślejsze powiązanie działań personalnych z celami biznesowymi przedsiębiorstwa uważane jest obecnie przez praktyków za najważniejsze wyzwanie dla menedżerów $\mathrm{HR}^{11}$.

Po trzecie, analiza problematyki poruszanej w wydanych w ostatnim okresie pozycjach literaturowych skłania do stwierdzenia, że dokonuje się zmiana mentalna w wartościowaniu elementów tworzących drzewo wartości przedsiębiorstwa i jedynym brakującym ogniwem jej transferu do praktyki są metody pomiaru kapitału intelektualnego (ale droga do ich określenia, choć niełatwa, wydaje się już dziś znacznie krótsza niż kiedyś). Coraz wyraźniejsze staje się przy tym podporządkowanie zarządzania [w znaczeniu ${ }^{2)}$ : $\bullet$ sekwencji funkcji (planowania, organizowania, motywowania i kontrolowania), • procesu decyzyjnego, • wykorzystywania potencjałów] celom efektywności ekonomicznej - realizowanym nie tylko w przestrzeni organizacyjnej przedsiębiorstwa (jak to jest w przypad$\mathrm{ku} \mathrm{zzl}$ ), ale i na otwartym rynku pracy (i to nie tylko krajowym) - a zatem gospodarowaniu.

Dostarczane są dowody, że jakość działań personalnych ma istotny wpływ na tworzenie wartości w przedsiębiorstwie ${ }^{3)}$. Trzeba zatem doskonalić te działania. Gospodarowanie kapitałem ludzkim ma być gospodarowaniem zorientowanym na wartość i uwzględniać działanie praw ekonomicznych ${ }^{4)}$.

Realizacji celów ekonomicznych służy także znajomość standardów europejskich w zzl ${ }^{5}$ i akceptacja znaczenia ich stosowania dla konkurencyjności przedsiębiorstw. Wprawdzie większość standardów dotyczy tradycyjnych funkcji personalnych (takich, jak wymienione w tabeli), ale są także wykraczające daleko poza nie, a dotyczące np. zarządzania informacją (nie redukowaną do komunikowania się w organizacji) czy kwestii społecznej odpowiedzialności przedsiębiorstw w sferze kapitału ludzkiego. Ta ostatnia kwestia łączy się zresztą także z zagadnieniem kształtowania wizerunku firmy przez jej działy personalne.

Widać zatem wyraźne związki zzl (poprzez: politykę rekrutacyjno-derekrutacyjną, w tymoutplacement) z problematyką rynku pracy (gkl w skali makro, a nie tak, jak to jest w przypadku zzl - wyłącznie w skali mikro), czyli z poszukiwaniem odpowiedzi na pytanie: w jakiej mierze polityka personalna przedsiębiorstwa może stanowić prewencję bezrobocia na lokalnym rynku pracy? Zależność zarządzania zasobami ludzkimi i ekonomii rynku pracy manifestuje się w szczególności poprzez: • współdziałanie pracowników urzędów pracy, agencji pracy tymczasowej i doradców personalnych z komórkami personalnymi firm, - wspólne korzystanie z raportów o wynagrodzeniach.

Literatura przedmiotu dotycząca standardów europejskich łączy się merytorycznie z zagadnieniami jakości zarządzania zasobami ludzkimi ${ }^{6}$, w których chodzi o atrybuty stosowanych sposobów obsługi kadr. I ona ma służyć celom ekonomicznym - zwiększeniu konkurencyjności przedsiębiorstw. Oczekiwanym wynikiem odpowiedniej jakości zarządzania jest bowiem odpowiednia jakość kapitału ludzkiego, charakteryzowana m.in. przez przedsiębiorczość pracowników. Jednak kwalimetria tego kapitału to zagadnienie jeszcze nie rozwiązane do końca (a być może nierozwiązywalne, dlatego powinno się raczej mówić jak to jest sugerowane ${ }^{7)}-\mathrm{o}$ doskonaleniu jakości personelu). W literaturze przedmiotu ${ }^{8)}$ analizowany jest także wpływ procesów zmianotwórczych na jakość zasobów ludzkich. Konieczne wydaje się również uwzględnianie wpływu wzrostu przeciętnego wieku pracownika (co może, w przypadku niewystarczających strumieni imigracyjnych, stanowić implikację przeobrażeń demograficznych w Polsce) i generalnie wzrostu różnorodności zasobów ludzkich (jako także efektu globalizacji i wirtualizacji) na jakość kapitału ludzkiego. Problematyka ta wykracza poza ramy zzl, 
Tab. Typologia funkcji personalnych

\begin{tabular}{|c|c|c|c|}
\hline Funkcja & Szczebel operacyjny & Szczebel taktyczny & Szczebel strategiczny \\
\hline $\begin{array}{l}\text { Badanie istniejącego stanu } \\
\text { personalnego }\end{array}$ & $\begin{array}{l}\text { Określanie profili zdolności } \\
\text { pracownika }\end{array}$ & $\begin{array}{l}\text { Agregacja kwalifikacji pra- } \\
\text { cowników }\end{array}$ & $\begin{array}{l}\text { Prognozowanie konfiguracji } \\
\text { personalnej i rachunek zaso- } \\
\text { bów ludzkich }\end{array}$ \\
\hline $\begin{array}{l}\text { Określanie zapotrzebowa- } \\
\text { nia na pracowników }\end{array}$ & $\begin{array}{l}\text { Określanie profilu wymagań } \\
\text { pracy i analiza czasu pracy }\end{array}$ & $\begin{array}{l}\text { Agregacja profili wymagań } \\
\text { pracy i ustalanie liczby osób } \\
\text { potrzebnych o danym profilu }\end{array}$ & $\begin{array}{l}\text { Prognozowanie wymagań } \\
\text { pracy oraz ilościowa specyfi- } \\
\text { kacja zapotrzebowania na } \\
\text { pracowników i planowanie } \\
\text { poliwalencji }\end{array}$ \\
\hline Rekrutacja i dobór & $\begin{array}{l}\text { Pozyskiwanie poszczegól- } \\
\text { nych pracowników i admini- } \\
\text { strowanie ich danymi }\end{array}$ & Analiza rynków pracy & $\begin{array}{l}\text { Marketing personalny (ka- } \\
\text { drowy, stanowisk pracy) }\end{array}$ \\
\hline Rozwój pracowników & $\begin{array}{l}\text { Planowanie i realizowanie } \\
\text { szkoleń, mobilności. } \\
\text { Strukturyzacja treści pracy }\end{array}$ & $\begin{array}{l}\text { Określanie kategorii adresa- } \\
\text { tów i kierunków rozwoju per- } \\
\text { sonelu }\end{array}$ & $\begin{array}{l}\text { Planowanie kontynuacji ob- } \\
\text { sady stanowisk }\end{array}$ \\
\hline Zwalnianie pracowników & $\begin{array}{l}\text { Planowanie i przeprowadza- } \\
\text { nie zwolnień indywidualnych }\end{array}$ & $\begin{array}{l}\text { Przeprowadzanie zwolnień } \\
\text { grupowych }\end{array}$ & $\begin{array}{l}\text { Prognozowanie zwolnień } \\
\text { w skali przedsiębiorstwa. } \\
\text { Określenie metod postępowa- } \\
\text { nia w przypadku konfliktów } \\
\text { na tle zwolnień }\end{array}$ \\
\hline $\begin{array}{l}\text { Redefiniowanie ról organi- } \\
\text { zacyjnych }\end{array}$ & $\begin{array}{l}\text { Weryfikowanie stopni przy- } \\
\text { datności pracowników do } \\
\text { pracy na dotychczasowych } \\
\text { stanowiskach }\end{array}$ & $\begin{array}{l}\text { Optymalne przyporządkowa- } \\
\text { nie pracowników do stano- } \\
\text { wisk pracy, ustalanie składu } \\
\text { zespołów pracowniczych, pla- } \\
\text { nowanie zmianowości pracy, } \\
\text { planowanie przedsięwzięć } \\
\text { z zakresu wzbogacania treści } \\
\text { pracy }\end{array}$ & Humanizacja pracy \\
\hline $\begin{array}{l}\text { Kształtowanie postaw i za- } \\
\text { chowań pracowników }\end{array}$ & $\begin{array}{l}\text { Motywowanie, ocenianie, ko- } \\
\text { munikowanie się }\end{array}$ & $\begin{array}{l}\text { Określanie zasad motywowa- } \\
\text { nia, oceniania, komunikacji }\end{array}$ & $\begin{array}{l}\text { Diagnozowanie i przekształ- } \\
\text { canie kultury organizacyjnej }\end{array}$ \\
\hline $\begin{array}{l}\text { Zarządzanie kosztami } \\
\text { pracy }\end{array}$ & $\begin{array}{l}\text { Określanie indywidualnych } \\
\text { wynagrodzeń }\end{array}$ & $\begin{array}{l}\text { Ustalanie budżetów kosztów } \\
\text { pracy }\end{array}$ & $\begin{array}{l}\text { Strukturyzacja kosztów } \\
\text { pracy }\end{array}$ \\
\hline
\end{tabular}

Źródło: na podstawie: Ch. SCHOLZ, Personalmanagement, Vahlen, München 1989.

wyznaczone granicami przedsiębiorstwa. Czy ukształtuje się w związku z tym subdyscyplina: Gospodarowanie kapitałem ludzkim w warunkach wzrostu jego różnorodności (Diversity Management of Human Resources)?

W jakich relacjach pozostaje jakość i wartość zasobów ludzkich (w tym wartość kapitału intelektualnego)? Pytanie to jest retoryczne, a odpowiedź nakazuje łączne traktowanie tych zagadnień. W nowszej literaturze przedmiotu podkreśla się, że brakuje wciąż (mimo postępu w tej dziedzinie ${ }^{9)}$ ) akceptowanych przez praktyków rozwiązań. Być może wynika to z niedostatecznego wykorzystania w tej mierze łańcucha wartości, a także strategicznego zarządzania zasobami ludzkimi oraz narzędzi zarządzania ryzykiem personalnym.

Omawianie zagadnień strategii personalnych, mimo że już na stałe weszło w zakres zzl ogranicza się zazwyczaj do takich kwestii, jak:

- relacje pomiędzy strategią personalną a strategia na poziomie firmy,

- rodzaje strategii personalnych,

- metody analizy strategicznej personelu,
- wymogi dotyczące cech pracowników wynikające z różnych rodzajów strategii,

- metody pozyskiwania pracowników o strategicznych kwalifikacjach.

Zaobserwować można tu dwa podejścia: • pierwsze, „usamodzielniające” ważne funkcje personalne aż do przypisania im statusu strategii ${ }^{10)} \mathrm{i} \bullet$ drugie, określające sposoby kształtowania funkcji i narzędzi personalnych w warunkach stosowania danego rodzaju strategii na poziomie firmy ${ }^{11)}$.

Pierwsze podejście można traktować jako pochodną założenia, że kapitał ludzki i rozwiązania go dotyczące sa priorytetem, zaś drugie - jako podporządkowanie działań personalnych potrzebom strategii ogólnej firmy. Zauważyć trzeba, że kwestia „strategicznego podejścia do zarządzania zasobami ludzkimi" stała się nieodzownym elementem literatury przedmiotu z zakresu zarządzania strategicznego (a nie tylko: zzl). Jednak w warunkach globalizacji najważniejsze stają się międzynarodowe strategie personalne - patrzenie na inwestycje w kapitał ludzki i ich wykorzystywanie nie tylko (jak nakazuje zzl) przez pryzmat poszczególnych przedsiębiorstw. Z tej perspektywy 

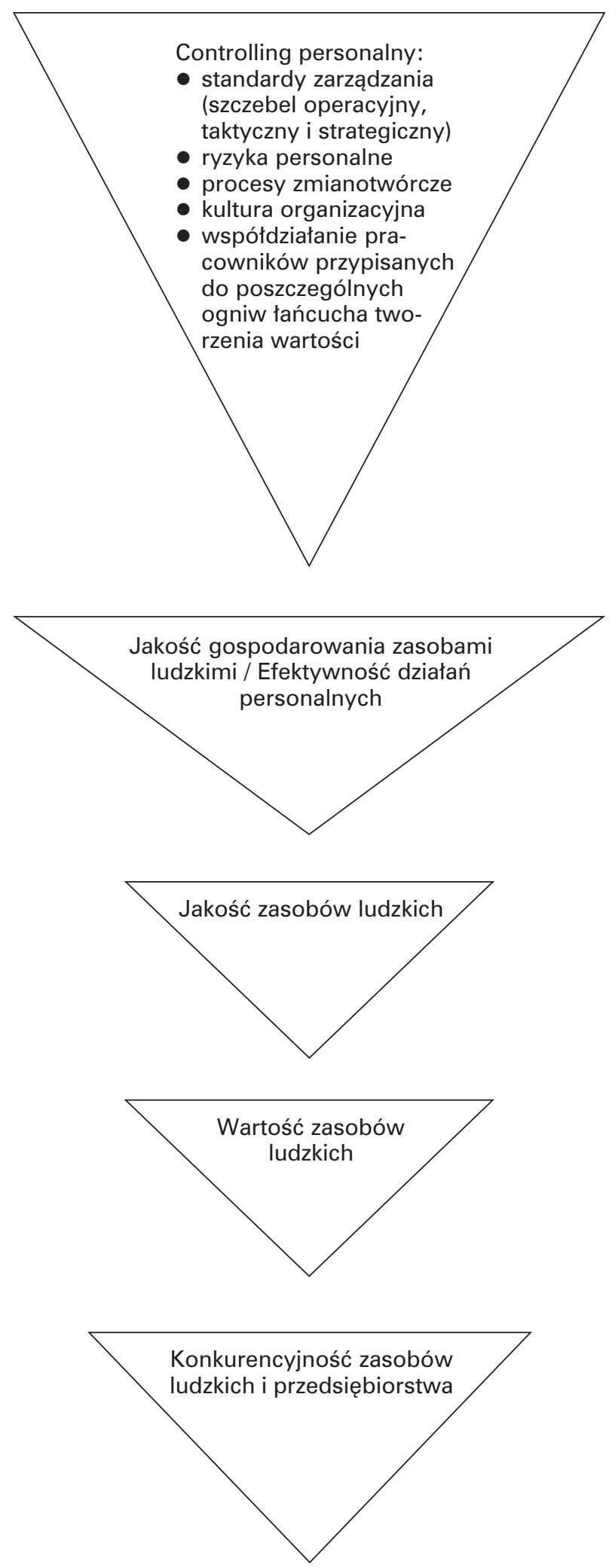

Rys. Nowa architektura systemu zzl / gkl Źródło: opracowanie własne.

jeszcze wyraźniejsza staje się potrzeba koherencji strategii personalnych i ekonomicznych w mikroi makroskali.

Jeśli chodzi o ryzyko personalne, to przede wszystkim brakuje empirycznej weryfikacji metod zarządza- nia nim, a także badań na temat występowania poszczególnych rodzajów tego ryzyka, na przykład na podstawie ich następującej typologii ${ }^{12)}$ :

- ryzyka funkcyjne (w tym m.in. ryzyko niedostosowania popytu i podaży pracy, ryzyko inwestowania w rozwój pracowników),

- ryzyka niespecyficzne ( $\mathrm{w}$ tym m.in. ryzyko logistyczne, ryzyko niekoherencji, ryzyko braku akceptacji rozwiązań, ryzyko formalizacji, ryzyko różnic kulturowych, ryzyko biometryczne),

- ryzyka innowacyjnego zarządzania zasobami ludzkimi (m.in. związane z: benchmarkingiem, outsourcingiem, organizacją sieciową, e-HRM),

- ryzyko utraty wizerunku na rynku pracy.

Być może zagadnienia ryzyka personalnego powinny zostać włączone do controllingu personalnego ${ }^{13)}$ jako rodzaj controllingu, a być może po prostu do ryzyka zarządzania firmą. W odniesieniu do controllingu personalnego zwrócić trzeba uwagę, że niektóre zagadnienia stanowiące jego treść poruszane są zarówno w literaturze przedmiotu interesującej specjalistów ds. personalnych ${ }^{14)}$, jak i w pozycjach z zakresu ekonomiki przedsiębiorstw ${ }^{15}$. Zwraca się uwagę, że stanowi on już narzędziowy standard ${ }^{16)}$. Być może sam controlling personalny powinien być mocniej sprzężony z pomiarem i sprawozdawczością kapitału intelektualnego, a zatem z finansami przedsiębiorstwa. A skoro stosowanie controllingu personalnego jest w obecnych, charakteryzujących się burzliwością otoczenia, warunkach nieodzowne, to nie można go redukować do kontrolowania jako funkcji zarządzania, gdyż - poza kontrolą - ma on także inne wymiary.

Zagadnienie strategii personalnych łączone jest niekiedy ${ }^{17)} \mathrm{z}$ marketingiem personalnym (marketingiem stanowisk pracy) - mówi się np. o przedsiębiorstwach realizujących strategię marketingu personalnego, podkreślając występującą w nich orientację także na „klienta wewnętrznego”, czyli pracownika. Marketing personalny łączy się też ze wspomnianym wcześniej public relations działów personalnych. Może być też traktowany jako realizacja rekrutacji i doboru pracowników na szczeblu strategicznym (por. tab.). Wydaje się, że marketing jest bliższy - ze względu na szerszy przestrzenny obszar oddziaływania - gospodarowaniu niż zarządzaniu.

Od lat zagadnieniem stale obecnym w literaturze przedmiotu z zakresu zzl jest kultura organizacyjna, co nie dziwi, gdyż należy ona do jego uwarunkowań (tzw. wewnętrznego kontekstu). Widać jednak obecnie wzrost zainteresowania nie tylko wpływem kultury na metody zzl w międzynarodowych przedsiębiorstwach $^{18)}$ i na efekty realizacji procesów zmianotwórczych $^{19)}$ (w tym przestrzeni funkcjonowania przedsiębiorstw), ale i kulturą jako determinantą konkurencyjności przedsiębiorstw ${ }^{20)}$.

Niełatwo jest odzwierciedlić aktualną architekturę zzl / gkl. Niewątpliwie służyć ma ona konkurencyjności przedsiębiorstwa osiąganej dzięki wysokiej jakości, a przez to i wartości jej kapitału ludzkiego. Na jakość tę wpływa jakość zarządzania zasobami ludzkimi. Jest ona wysoka, gdy:

- jest zgodna ze standardami zarządzania, 
- dotyczy nie tylko wymiaru operacyjnego, ale i taktycznego (traktowanego zupełnie „po macoszemu”) oraz strategicznego,

- antycypuje wpływ na sferę personalną procesów zmianotwórczych, w tym zmiany przestrzeni funkcjonowania przedsiębiorstw,

- pozostaje w harmonii z kształtowaniem pożądanej kultury organizacyjnej,

- uwzględnia ryzyka personalne.

Jakość zarządzania zasobami ludzkimi, tak jak każda jakość kosztuje. Nie dziwią więc publikacje traktujące o efektywności zzl rozumianej ogólnie i o efektywności poszczególnych działań personalnych, np. o rentowności inwestycji w kapitał ludzki ${ }^{21)}$. Interpretacja wartości wskaźników ekonomicznych (a taki charakter mają wskaźniki controllingu personalnego) następuje przy tym pod wpływem wymogów rynkowych. Instrumentem nadrzędnym do sterowania jakością i efektywnością zarządzania zasobami oraz wartością i konkurencyjnością kapitału ludzkiego pozostawałby controlling (por. rysunek) jako instrument planowania i kontrolowania procesów gospodarowania.

Podsumowując, skoro zamiast „zasoby ludzkie” mówimy coraz częściej „kapitał intelektualny”, a zarządzanie zasobami ludzkimi podporządkowywane jest w praktyce i teorii wyraźniej niż dotychczas (łączącemu wymiar mikro- i makroekonomiczny) celom gospodarowania oraz nasycane coraz mocniej słownictwem charakterystycznym bardziej dla katedr ekonomii niż katedr zarządzania, to być może należy po prostu określenie „zarządzanie zasobami ludzkimi” zastąpić określeniem ,gospodarowanie kapitałem ludzkim”. Nie chodzi przy tym o kosmetyczną etykietyzację, lecz o nazwanie dokonujących się zmian adekwatnym do nich imieniem.

Autorka zdaje sobie sprawę, że wiele wyrażonych tu poglądów ma charakter dyskusyjny i być może sama już niedługo będzie dokonywała ich przewartościowania. Jest jednak zdania, że potrzebne jest rejestrowanie kolejnych przewartościowań poglądów, dokonujących się pod wpływem obserwacji i analizy przeobrażeń w sferze personalnej. Zaznaczyć także trzeba, że architektura gospodarowania kapitałem ludzkim w poszczególnych firmach musi być zróżnicowana, gdyż różne układy funkcji personalnych (i np. różny stopień ich centralizacji / decentralizacji) - w zależności od realizowanej strategii i obszaru funkcjonowania - będą stanowiły w nich strukturę maksymalizujaccą korzyśsi wynikające z zatrudniania kapitału ludzkiego. Zresztą zmienia się nie tylko architektura gospodarowania kapitałem ludzkim, ale także narzędzia zorientowane na uzyskanie korzyści z zatrudnienia. $\mathrm{Na}$ przykład tradycyjne kontrakty pracowników z firmą typu: lojalność za stabilność zatrudnienia sa wypierane nowymi kontraktami: aktywność na rzecz utrzymania konkurencyjności własnej i przedsiębiorstwa w zamian za szanse rozwoju ${ }^{22}$. Nowe kontrakty niewątpliwie lepiej wpisują się w architekturę gkl niż $\mathrm{w}$ architekturę zzl, gdyż ich słowem - kluczem jest konkurencyjność.

prof. dr hab. Anna Lipka Akademia Ekonomiczna w Katowicach Wydział Ekonomii
PRZYPISY

1) Por.: Zarzadzanie informatycznie wspomagane. Rozmowa $\mathrm{z}$ Row Henson, międzynarodową konsultantką ds. systemów informatycznych w zarządzaniu kadrami, „Personel i Zarządzanie" 2005, nr 1, s. 21.

2) Por.: Dźwignia Archimedesa, czyli metody i techniki zarzadzania. Teoria i praktyka, praca zbiorowa pod red. naukową S. DUCHNIEWICZA, Wydawnictwo Menedżerskie PTM, Warszawa 2004, s. 25-30 i 575.

3) Por.: M. HEIDECKER, Wertorientiertes Human Capital Management - zur Steigerung des Unternehmenswertes durch die Personalarbeit, DUV, Wiesbaden 2003; P.-R. PERSCH, Die Bewertung von Humankapital - eine kritische Analyse, Hampp, München - Mering 2003.

4) Por.: G. URBANEK, Kapitat intelektualny w procesie tworzenia wartości, „Przegląd Organizacji” 2004, nr 12, s.13.

5) Standardy europejskie $w$ zarzadzaniu zasobami ludzki$m i$, praca zbiorowa pod red. M. JUCHNOWICZ, Poltext, Warszawa 2004.

6) Zob.: Jakość zarzadzania przedsiębiorstwem, praca zbiorowa pod red. naukowa A. SAJKIEWICZ, „Monografie i Opracowania" nr 455 (IFGN 39), SGH, Warszawa 1998.

7) Jakość zasobów ludzkich. Kultura, kompetencje, konkurencyjność, praca zbiorowa pod red. A. SAJKIEWICZ, Poltext 2002 , rozdz. II.

8) L. SKAÆECKA, Jakość zasobów ludzkich w warunkach restrukturyzacji przedsiębiorstwa, Wydawnictwo UMCS „Annales”, Lublin 2001.

9) Istniejące rozwiązania $\mathrm{w}$ tej dziedzinie prezentuje m.in. książka: B. MIKUŁA, A. PIETRUSZKA-ORTYL, A. POTOCKI, Zarzadzanie przedsiębiorstwem XXI wieku. Wybrane koncepcje $i$ metody, Difin, Warszawa 2002, s. 3768; zob. też: R.S. KAPLAN, D.P. NORTON, Strategiczna karta wyników. Jak przetożyć strategię na dziatanie, PWN, Warszawa 2002.

10) Zob.: S. BORKOWSKA, Strategie wynagrodzeń, Oficyna Ekonomiczna, Kraków 2001.

11) Z. JANOWSKA, Zarzadzanie zasobami ludzkimi, PWE, Warszawa 2002, s. 24-25.

12) A. LIPKA, Ryzyko personalne. Szanse i zagrożenia zarzadzania zasobami ludzkimi, Poltext, Warszawa 2002.

13) S. MARCINIAK, Controlling. Filozofia, projektowanie, Difin, Warszawa 2004, s. 52-54.

14) Z. SEKUŁA, Controlling personalny. Część 2: Strategie personalne, zadania $i$ narzędzia controllingu personalnego, Oficyna Wydawnicza Ośrodka Postępu Organizacyjnego, Bydgoszcz 2000.

15) Ekonomika matych $i$ średnich przedsiębiorstw, praca zbiorowa pod red. G. SOBCZYK, Difin, Warszawa 2004, s. $150-181$.

16) Standardy europejskie..., op.cit., s. 32.

17) M. ZIELIŃSKI, Zwiazki między strategiami personalnymi a rynkiem pracy, [w:] Zarzadzanie zasobami ludzkimi $w$ warunkach nowej gospodarki, praca zbiorowa pod red. Z. WIŚNIEWSKIEGO i A. POCZTOWSKIEGO, Oficyna Ekonomiczna, Kraków 2004, s. 141.

18) Międzynarodowe zarzadzanie zasobami ludzkimi, praca zbiorowa pod red. A. POCZTOWSKIEGO, Oficyna Ekonomiczna, Kraków 2002.

19) Zarzadzanie zasobami ludzkimi w procesach fuzji i przejęć, praca zbiorowa pod red. A. POCZTOWSKIEGO, Oficyna Ekonomiczna, Kraków 2004.

20) Zob.: B. FRYZE€, Kultura a konkurencyjność przedsiębiorstwa, Wydawnictwo Dom Organizatora, Torun 2004.

21) Zob.: J.J. PHILLIPS, R.D. STONE, P.P. PHILLIPS, Ocena efektywności w zarzadzaniu zasobami ludzkimi. Praktyczny podrecznik do pomiaru rentowności inwestycji, Human Factor, Kraków 2003.

22) G. JOHNSON, J. FRITZSCHE, M.H. BERTRAND, Grenzen überwinden, „Personal” 2005, nr 1, s. 18-19. 